\title{
A perspectiva brasileira sobre a pobreza: um estudo de caso do Programa Bolsa Família
}

Sarah Mailleux Sant'Ana

\section{Introdução}

Este artigo inicia-se com a definição institucional de pobreza - ou seja, uma definição fundamentada na maneira como as instituições tratam a questão dada pelo sociólogo alemão Georg Simmel. Traçado este pano de fundo, traz, na seqüência, uma abordagem mais substancial da pobreza e da relação entre trabalho e precariedade, tema abordado por Robert Castel. Em seguida, apresenta uma breve descrição do funcionamento do Programa Bolsa Família e alguns aspectos relacionados aos conceitos e modos de tratamento da questão da renda e da educação, bem como da família e dos modelos familiares. O texto aborda ainda alguns desafios administrativos para o Estado na gestão do Programa e os preconceitos morais e sociais recorrentemente veiculados em relação ao Programa. Por fim, na conclusão, busca retomar a análise do Bolsa Família, seus limites e desafios, defendendo a necessidade de participação de todos em um pacto social contra a pobreza e a desigualdade no Brasil. 
$\mathrm{O}$ artigo é fruto de questionamentos e de alguns estudos acadêmicos, assim como de documentos de ministérios, de organismos internacionais e de centros de pesquisa e estatísticas sobre a pobreza e a desigualdade, tendo como estudo de caso o Programa Bolsa Família. É resultado também de um trabalho de campo realizado, entre julho e agosto de 2006, em Formosa de Goiás e na fronteira entre Bahia, Alagoas e Pernambuco, por meio de observação participante e entrevistas semi-diretivas. Não se tem a pretensão, aqui, de apresentar algo necessariamente novo, tampouco de tratar o tema, em poucas páginas, na profundidade necessária. Trata-se apenas das primeiras interrogações e considerações de um estudo que deve ser aprofundado nos anos a seguir.

\section{Definição institucional da pobreza: Georg Simmel}

Georg Simmel apresenta na sua obra Les pauvres (Os pobres) uma definição institucional de pobreza. A importância de sua obra está no esclarecimento dos problemas de definição de pobreza e na compreensão proposta dos modos de constituição da categoria "pobres" e os vínculos que os ligam à sociedade como um todo. Segundo Paugam e Schultheis, que redigem o prefácio da edição utilizada neste artigo, a abordagem construtivista de Simmel rompe com todos os tipos de conceitos naturalistas que estão em voga nos debates científicos e políticos atuais. Originalmente escrito no início do século $\mathrm{XX}$, o texto é bastante atual para o debate sobre a pobreza e a exclusão social e explicita as perspectivas sócio-históricas dos modos de regulação dos vínculos sociais. Esse texto pode ser considerado como o ponto de partida da sociologia da pobreza, que não se reduz a um campo específico da sociologia, mas refere-se às questões fundamentais dos vínculos sociais e visa gerar proposições teóricas mais gerais (Simmel, 2005, p.2).

De acordo com Simmel, a pobreza não pode ser definida como um estado quantitativo em si mesmo, mas como uma relação à reação social que resulta de uma situação específica. A pobreza é, assim, relativa e construída socialmente, seu sentido é dado pela sociedade (2005, p. 97). Paugam e Schultheis alinham-se a Simmel quando colocam que a pertinência sociológica da abordagem à pobreza não é relativa à pobreza em si mesma ou aos pobres, mas às formas institucionais (acadêmicas, políticas e mesmo morais) que são escolhidas em determinado momento histórico, em uma determinada sociedade. De acordo com o sociólogo alemão, a definição de pobreza que diz que "É pobre aquele cujos meios não são suficientes para alcançar os fins"1 (2005, p. 91) é individualista e limitada em sua aplicação prática porque oferece a falsa impressão de que "certos fins podem ser considerados independentes de toda decisão arbitrária e (de modo) puramente pessoal". A pobreza é relativa porque não corresponde "à relação entre os meios individuais reais, mas aos fins vinculados ao indivíduo, a priori social, que varia de acordo com o status" (2005, p. 92). Nessa situação particular, os pobres não estão "fora" da sociedade, mas em uma situação de dependência da coletividade. Simmel demonstra que "é somente a partir do momento em que eles são assistidos ou do qual a sua situação global passa a exigir assistência, mesmo que ainda não tenha sido efetivamente dada, que eles se tornam membros de um grupo caracterizado pela pobreza" (2005, p. 9). 
Simmel afirma que "a assistência constitui uma parte da organização do todo, ao qual pertencem os pobres e os proprietários" (2005, p. 60). Os pobres são submetidos a um estado de inclusão perversa por uma comunidade que lhes atribui posição marginal. A ação da coletividade em relação aos pobres limita-se ao mínimo para preservá-los da degradação física, assegurando-se que recebam aquilo a que têm direito, mas que não recebam "demais". Simmel tem um olhar bastante crítico com relação à filantropia privada e pública, uma vez que essas ações não seriam um fim em si mesmo, mas um meio de manter a coesão e o vínculo social. A assistência, nesse caso, seria destinada a uma faixa da sociedade e teria caráter pessoal (ou seja, cobriria apenas as necessidades individuais de seus beneficiários), sendo, paralelamente, na realidade, uma ação que sustenta, sobretudo, aqueles que não estão na precariedade, resultando uma situação em que o bem cabe mais propriamente ao doador do que ao recebedor. $\mathrm{O}$ sociólogo mostra ainda que "enquanto o custo dos pobres for absorvido pelos impostos e a assistência resultar de receitas constantes ou de bens estatais, esse vínculo (entre pobres e o resto da sociedade) é perfeito. A assistência aos pobres torna-se uma função da totalidade em si e não mais a soma dos indivíduos, como no caso do custo dos pobres" (2005, p.88). Ou seja, é um custo absorvido pela totalidade da sociedade e não apenas por aqueles que fazem "caridade" ou pelo próprio pobre.

Paugam e Schultheis afirmam, com base em Simmel, que existe um utilitarismo primário da sociedade, uma vez que a assistência aos pobres constituiria um meio de assegurar sua proteção e autodefesa. A finalidade da assistência seria a de mitigar as diferenciações sociais extremas, de forma a permitir que a estrutura social continue a fundar-se sobre essa diferenciação e, conseqüentemente, mantenha o status quo social. Ele observa igualmente que o Estado referese ao princípio da obrigação de assistir aos pobres, mas essa obrigação não se traduz em um verdadeiro direito aos pobres, tanto que estes não têm nenhum recurso possível, se a assistência lhes é recusada. Apenas a coletividade, destaca Simmel, pode mudar as circunstâncias econômicas e culturais

"Agrandereferência de integração social continua sendoo trabalhoe espera-se daqueles que não trabalham (pordiversos motivos) que consigam responder à sociedadee aomercado detraballo comosevivessemo individualismo positivo."

fundamentais que provocam a condição da pobreza, cabendo-lhe também "a tarefa de mudar essas circunstâncias, de modo que ofereçam a menor possibilidade de empobrecimento resultante de fraqueza individual, de propensões desfavoráveis, de falta de oportunidade ou de privações" (2005, p. 85).

A análise apresentada por ele no início do século XX em relação às sociedades 
européias, que encontra eco até hoje, também reflete-se em parte da luta contra a pobreza no Brasil. Ao longo de vários séculos, a assistência foi tratada como uma caridade filantrópica, mascarando o caráter de manutenção do "nível ótimo de miséria", ou seja, um nível que não ameaça as classes mais abastadas, evita a distribuição efetiva de bens e possibilidades e não esgarça definitivamente o tecido social. Nessa perspectiva, boa parte das ações públicas escolheu diversos modos de definir e redefinir a contagem dos pobres para "combater a pobreza" - "os pobres são aqueles a quem assistimos" -, o que demonstra a pertinência da abordagem institucional da pobreza. Até hoje os instrumentos e as definições de categorias sociais não são evidentes. Existem instrumentos concorrentes, diversas polêmicas que geram ações divergentes, mas, sobretudo, limitadas. Neste texto será explicitada, brevemente, parte da discussão que gira em torno dessas categorias, mas nenhuma definição específica será escolhida, mantendo, portanto, a fluidez como é tratada em diversos textos.

A importância da definição institucional da pobreza reside no fato de que ela nos alerta sobre a constituição da categoria "pobres" e o modo pelo qual, historicamente, a definição institucional sobre "quem devemos assistir" e "quem consideramos pobres" pode variar bastante. Entretanto, essa definição institucional pode não ser suficiente para fazer frente à experiência social da pobreza e da precariedade, que inclui: a falta da autonomia econômica, a questão $\mathrm{da}$ insegurança alimentar, a precariedade habitacional, a baixa escolaridade, pouco acesso à saúde, a questão do reconhecimento social, de gênero e étnicas, entre outros. Nas abordagens de combate à pobreza, na maioria das vezes, há uma seleção de duas ou três dessas categorias, mas que não abarcam a totalidade $\mathrm{da}$ experiência da pobreza ${ }^{2}$.

\section{Por uma análise mais subs- tancial da pobreza}

Robert Castel, no seu livro de 1995, A metamorfose da questão social, apresenta uma caracterização sócio-histórica das metamorfoses da situação do trabalho e da coesão social na França. O autor utiliza conceitos que podem ajudar a esclarecer algumas questões acerca da definição de pobreza.

Castel compreende o trabalho não como uma questão técnica, mas como um apoio privilegiado de inserção na estrutura social. Ele demonstra que há uma forte relação entre o lugar ocupado na divisão social do trabalho e a participação nas redes de sociabilidade e nos sistemas que protegem o indivíduo face aos "riscos" da existência. Segundo o autor, a vulnerabilidade social é um espaço intermediário e instável, que conjuga a precariedade do trabalho e a fragilidade dos apoios de proximidade. Por outro lado, a situação de precariedade do trabalho tende a equilibrar-se com o fortalecimento do apoio de proximidade e pode assegurar a sobrevivência de indivíduos nas situações extremamente precárias. O autor afirma que a pobreza como discriminante econômico não é a questão essencial, apesar de desempenhar um papel importante na desestabilização daqueles que são/estão desprovidos de reservas econômicas. A seu ver, a questão principal está entre a precariedade econômica e a instabilidade social (2001, p. 19).

Castel prefere trabalhar sobre o conceito de desafiliação que de exclusão. Ele acredita que o termo "exclusão" refere-se 
a um estado imóvel de constatação de carências, sem levar em conta os processos que criam essa situação. A desafiliação é o resultado de um processo de invalidação social, desqualificação e dissociação. Nessa situação, a vulnerabilidade social detém uma posição estratégica, pois se a vulnerabilidade é controlada ou reduzida, ela assegura a estabilidade da estrutura social. Mas quando ela é aberta e está em expansão, alimenta as turbulências que fragilizam as situações já existentes e desfaz o status que antes era assegurado.

Ele afirma que a vulnerabilidade é uma marca de incerteza e, mais freqüentemente, de infelicidade (2001, p.26). A incerteza, aqui, refere-se ao futuro, e a vulnerabilidade em estado quase permanente gera infelicidade. Castel demonstra que, mesmo que a precariedade tenha se transformado ao longo da história, as populações que as viveram e vivem estão em posições análogas. Os processos que produziram essas situações são comparáveis, ainda que as manifestações sejam distintas, pois as dinâmicas são as mesmas. Contudo, não existe uma linearidade, mas bifurcações e descontinuidades. Para o autor, a questão social é o enigma da coesão e do risco de fratura de uma sociedade em que as populações podem ser, ao mesmo tempo, atores e vítimas do que lhes acontece. Afir$\mathrm{ma}$, ainda, que existe um hiato entre a organização política e o sistema econômico, que marca o lugar do social, o qual consistiria em sistemas de regulação não mercantis instituídos para cobrir aquela lacuna.

A desafiliação não é um conceito que possa ser usado para a realidade brasileira do mesmo modo que Castel utiliza para a realidade francesa, pois, no Brasil, nunca se observou uma proteção social como na França ${ }^{3}$. No entanto, o termo desafiliação pode ser utilizado com a apropriação de dois conceitos-chave: como o resultado de um processo e não um estado estático e como a ausência de apoio e segurança.

Castel trabalha também sobre a questão de surnuméraires ("sobre numerosos") na sociedade. Surnuméraires são os que não podem nem mesmo ser considerados explorados porque não possuem competências que sejam convertíveis em valor social, assim como não representam nenhuma força de pressão ou de luta porque não fazem parte de um setor nevrálgico da vida social. De um lado, são “inexistentes" porque não são socialmente úteis, mas, ao mesmo tempo, são presentes e numerosos. Ele afirma que há tentativas de "eufemizar" a sua presença por uma integração que parece apagar o problema. Castel afirma também que não há espaço de autonomia para essas populações situadas à margem, exceto ratificando o corte que se denuncia pretendendo lutar contra a exclusão (2001, p. 29).

O núcleo da questão social para Castel é o trabalho, permeado hoje pela questão dos surnuméraires e de suas condições nebulosas fundadas sobre a precariedade e a incerteza do dia de amanhã, transformando-se na vulnerabilidade de massa. Os "indolentes" são os indivíduos desafiliados a tal ponto que não podem inscrever-se em nenhum coletivo e, sendo desafiliados e desprovidos, são super expostos e descosturados do tecido que estrutura a sociedade. Eles sofrem o que Castel chama de "individualismo negativo", que se revela em termos da falta de bens, de relações estáveis, de segurança, de consideração, de reconhecimento, de afiliação e de apoio em relação à transmissão familiar, ao trabalho e à possibilidade de criar um futuro. É um individualismo por falta de enquadramento.

A sociedade, por outro lado, exige que seus integrantes respondam com um 
"individualismo positivo" para compor o conjunto da sociedade em bases contratuais, as quais se fundam sobre a autonomia e liberdade e sobre um coletivo que une apenas o contratante ao contratado. Os surnuméraires, entretanto, não têm a mesma autonomia daqueles que vivem o individualismo positivo, mas uma autonomia resultante da falta de apoio e uma liberdade resultante da falta de relações estáveis.

Essa relação contratual da qual Castel se refere não pode ser aplicada diretamente à realidade brasileira, pois apenas uma pequena parte da população tem sua relação de trabalho assegurada contratualmente (pela carteira de trabalho) e a seguridade social é muito distinta da francesa. No entanto, não se pode deixar de notar que a grande referência de integração social continua sendo o trabalho e que se espera daqueles que não trabalham (por diversos motivos) que consigam responder à sociedade e ao mercado de trabalho como se vivessem o individualismo positivo. Isso se reflete no discurso comum de que "o povo não trabalha porque não quer", "o povo não tem iniciativa, não é pró-ativo e por isso não melhora de vida".

Os contratos, por sua vez, diz Castel, tornam-se cada vez menos individualizados e inscrevem os trabalhadores em "pactos de adesão", com regras gerais de direito do trabalho e de proteção social. Em outros termos, o mundo do trabalho não forma um mundo de indivíduos, mas, antes, "uma sobreposição hierárquica de coletividades constituídas com base na divisão do trabalho e reconhecidas pelo direito" (2001, p. 756). Isso corrobora para uma flexibilização do trabalho e das relações fora dele. Existe, a partir disso, uma segmentação do trabalho e aumento de serviços que exigem dos indivíduos redefinição de sua identidade profissional e mobilização de recursos tanto de capital pessoal, quanto de competência técnica geral (não basta saber vender um produto, é preciso saber se vender também).

Isso gera resultados diferentes segundo grupos sociais diferentes. Para alguns, permite escapar dos constrangimentos coletivos e exprimir sua identidade pelo trabalho, enquanto, para outros, significa precariedade, isolamento e perda de proteções.

Nas formas de individualização modernas, o individualismo negativo é qualificado, como descrito anteriormente, pela falta de possibilidades efetivas de realização de si mesmo na vida coletiva (2001, p. 757). O individualismo positivo é o seu oposto, uma série de possibilidades asseguradas socialmente pela coletividade. Essa disparidade é também sentida na vida social: na classe média, a individualidade é traduzida em uma relação agradável e narcisista, enquanto, nas classes mais desprovidas, ela se traduz pelo individualismo negativo. Trata-se de um modo de articulação indivíduo-coletivo que apresenta efeitos de contraste, pois existe um reforço do individualismo positivo de um lado, ao mesmo tempo em que nascem a insegurança e a falta de proteção social em massa, de outro. Sempre existiram, afirma Castel, "os pobres bons" e os "pobres maus", distinção sempre operada por critérios morais e psicológicos.

Para ele, a contradição do processo atual de individualização coloca duas ameaças à sociedade: a fragmentação, que a deixaria ingovernável, e a polarização entre aqueles que podem viver a individualização de modo positivo, uma vez que estão assegurados socialmente, e aqueles que vivem a individualização negativa, pela falta de afiliação. A única instância que pode criar 
uma ponte entre os dois pólos de individualização e impor um mínimo de coesão social é o poder público, pois os constrangimentos econômicos são muito fortes e vários vínculos de solidariedade mostram-se muito fracos diante dos desafios modernos. $\mathrm{O}$ que deve ser levado em conta é que a condição daqueles que estão "fora" depende da condição daqueles que estão "dentro", já que as orientações emanadas dos centros de decisões econômicas e sociais repercutem diferentemente nas diferentes áreas da vida social.

Os vulneráveis, os integrados e os desafiliados fazem parte de um mesmo conjunto, cuja unidade é problemática. Castel levanta, então, a seguinte questão: se a eficiência econômica e social da sociedade francesa contemporânea depende da exclusão social de $10 \%$ a $30 \%$ da população, como é possível ainda falar-se de "conjunto social"? No Brasil, essa porcentagem é ainda mais elevada, como veremos em outros dados. A pergunta aplica-se ainda mais gravemente à sociedade brasileira: qual é a tolerância de uma sociedade democrática que invalida socialmente uma grande parte de sua população?

\section{Emprego, trabalho e família no Brasil}

Segundo os conceitos trabalhados por Castel e a categorização de qualificação e competência, pode-se concluir que a grande maioria da população brasileira vive o individualismo negativo, resultado de gerações sem acesso à escolarização e de exploração social. Segundo dados da PNAD/2004, entre os que declaram trabalhar, apenas $35 \%$, em média, têm carteira assinada e 25\% são "autônomos". Essa categoria abarca distintas situações. Por um lado, inclui os trabalhadores que escolhem a autonomia, caso, por exemplo, de um consultor autônomo, que pode assegurar seus direitos e seu futuro por meios privados. Por outro, a maioria dos autônomos é composta de indivíduos em situação precária: empregados domésticos (faxineiras, jardineiros, babás), trabalhadores da construção civil, agricultores que trabalham sazonalmente em plantações de médios ou grandes proprietários, entre outros.

O nível de ocupação a partir dos 10 anos é de 56,5\%, sendo $68,2 \%$ dessa população masculina e $45,6 \%$, feminina (PNAD/2006). Por faixa etária, existem $10,1 \%$ de trabalhadores entre 10 e 14 anos; $77,9 \%$ entre 30 e 39 anos e $29,9 \%$ a partir dos 60 anos. Em todas as faixas etárias, existem mais homens que mulheres. O trabalho doméstico e a educação das crianças não fazem parte do cálculo de trabalho. As atividades econômicas foram reagrupadas em cinco segmentos: 40,5\% trabalham na categoria de serviços; $21 \%$ na agricultura; $17,3 \%$ no comércio e reparação (consertos de máquinas e automóveis); $14,7 \%$ na indústria e 7\% na construção civil. Essa distribuição varia segundo as regiões do País. No Sudeste e Centro-Oeste, entre $45 \%$ e $47 \%$ da população encontra-se na área de serviços; no Sul e Sudeste existe entre $17,7 \%$ e $18,5 \%$ da população na indústria; no Nordeste, há 36\% da população na área agrícola. No comércio e na reparação, assim como na construção civil, não há grande variação entre as regiões.

A região Nordeste apresenta a maior proporção de trabalho sem carteiras assinadas e a Sul, a maior proporção de trabalhadores com carteira assinada. $\mathrm{Na}$ divisão de gênero, 2/3 das mulheres trabalham em quatro grupos de atividade: serviços domésticos, educação, saúde e serviços sociais, enquanto $70 \%$ dos homens trabalham na agricultura, comércio e 
reparação, indústria e construção. Na categoria de trabalhadores sem remuneração, na produção de consumo próprio e na construção para a utilização própria, existem $7,8 \%$ de homens e $15,6 \%$ de mulheres.

É por causa desses quadros de precariedade e de insegurança social que a educação é também compreendida como um elemento de emancipação da situação de pobreza e instabilidade social. Existe uma percepção aguda de que a obtenção de um melhor emprego (e mesmo a carteira assinada), melhor remuneração, trabalhos menos exigentes fisicamente e de maior reconhecimento social depende de um nível de escolaridade mais elevado.

Nas entrevistas feitas entre 1995 e 1999 , na cidade de Campinas, pelo Núcleo de Estudos de Políticas Públicas (NEPP/ Unicamp), os beneficiários do Programa de Renda Familiar Mínima (PGRFM), implementado por esse município, revelaram questões ligadas à precariedade, à educação e ao trabalho. A baixa escolarização e a realização de trabalhos físicos criam um viés de gênero. Segundo os entrevistados, os homens, que são reconhecidos como detentores de "força física", têm diversas possibilidades de ocupações, enquanto as mulheres com o mesmo nível de escolaridade só têm acesso às ocupações reconhecidas como inferiores. Isso explicita uma necessidade ainda mais intensa de escolarização das mulheres. No entanto, se o nível educacional é percebido como uma capacitação que pode viabilizar trabalhos mais reconhecidos, os beneficiários também testemunharam que as relações de trabalho estão imersas em um universo de relações pessoais, enviesadas, ainda, pela questão de idade e da "cor da pele" (FonseCA, 2001, p. 201). Ao mesmo tempo em que a educação é associada à ascensão social, é também delimitada por faixa etária e escolaridade: é importante estudar, mas é igualmente importante trabalhar. Portanto, diversas famílias permitem o estudo exclusivo até os 14 anos, mas, a partir de então, passa a existir uma conjugação de trabalho diurno e estudo noturno.

A pobreza é compreendida, em diversos casos, como resultado do desemprego ou da ausência de emprego estável e de exigências exageradas para poder alcançar certos cargos ou empregos. Nos últimos anos, mesmo funções como limpar salas, ser lixeiro, preparar cafezinho em instituições públicas e privadas exigem segundo grau completo. Segundo os entrevistados, o desemprego ou a ausência de carteira assinada provocam prejuízos à figura pública daqueles que vivem nessas condições, já que a carteira assinada funciona como um "passaporte" em diversas esferas sociais, gerando credibilidade para futuros empregadores e um atestado de "boa pessoa" (FOnSECA, 2001, p. 207).

Se o trabalho é um apoio de inscrição privilegiada na estrutura social como afirma Castel e, obviamente, fonte de renda familiar, grande parte da população brasileira vive uma situação ambígua: ela trabalha (a partir da infância), mas o faz em situações tão precárias que essa inscrição é também insuficiente. Faz-se referência aqui aos empregos informais, sem carteira assinada e contratos precários. Nesse quadro, são as relações de solidariedade, de vizinhança e de famílias ampliadas que asseguram sua sobrevivência.

Ainda de acordo com os entrevistados na pesquisa realizada em Campinas, a educação é vista como uma porta de entrada ao mundo do trabalho, mas não uma garantia. Daí a necessidade de começar a trabalhar a partir dos 14 anos e aumentar a possibilidade de sobrevivência. Se o trabalho é a chave do combate à 
pobreza, o aumento de programas com a distribuição de benefícios sociais é resultado direto do desemprego e da precariedade do trabalho.

Esse panorama mostra como a experiência social de integração social brasileira pelo trabalho é vivida, sobretudo, pelo individualismo negativo. Essa situação gera precariedade individual e familiar e explicita a necessidade de ações que tratem da situação real ou potencial da precariedade e da pobreza.

\section{Apresentação do Programa Bolsa Família}

O Programa Bolsa Família (PBF) nasceu das experiências anteriores dos programas de distribuição de renda e como um primeiro passo ao projeto de "renda de cidadania", de autoria de Eduardo Suplicy, votado em 2004. A tese de doutorado de Ana Maria Medeiros Fonseca, defendida na Universidade de Campinas, em 2001, teve grande influência na configuração do Programa. A partir de seu trabalho sobre o conceito de família na visão de políticas públicas e sobre o modo pelo qual as famílias representam-se e apresentam a si mesmas, o Programa foi constituído sobre um modelo familiar mais adequado à realidade brasileira, como será explicado mais adiante.

É importante ressaltar que as escolhas relativas a um programa público e o seu modo de funcionamento refletem o modus operandi de um Estado. Como Simmel demonstra, a forma de calcular "quem assistimos", a escolha do público-alvo, os critérios de abordagem (à pobreza), as condicionalidades da assistência e as eventuais penalidades de um programa refletem uma concepção de sociedade, de investimento social e em última instância, uma filosofia de Estado.

O Programa Bolsa Família tem uma vertente emergencial (transferência direta de renda aos beneficiários e acompanhamento básico de saúde) e uma vertente de longo prazo (educação infanto-juvenil). No entanto, se não for fortalecido por outras ações, terá ainda um resultado limitado, uma vez que a questão da pobreza no Brasil passa pelo desemprego massivo, por problemas de reconhecimento social, por dificuldades de criar e manter um ensino gratuito de qualidade, por carências de infra-estrutura que interferem no saneamento básico e na saúde, etc.

\section{O funcionamento do Programa Bolsa Família}

O Programa Bolsa Família é uma iniciativa entre diversas outras que constitui o Programa Fome Zero como um todo. Dentro do Fome Zero, pode-se citar: o Pronaf, o Alimentação Escolar, as Ações de Trabalho e Renda e o Luz para Todos, entre outros. O Programa Bolsa Família é o maior programa de transferência de renda já realizado na história do País, também reconhecido como a maior experiência com tais características em curso atualmente no mundo ${ }^{4}$.

Pela transferência de renda direta às famílias de beneficiários, o governo tem por objetivo combater a pobreza e a extrema pobreza. Hoje, o PBF está presente em 5.560 municípios e no Distrito Federal e alcançou mais de 11 milhões de famílias em 2006 (aproximadamente 44 milhões de pessoas). Os recursos do Programa são distribuídos de acordo com as taxas de pobreza e extrema pobreza: $8 \%$ ao Norte, $50 \%$ ao Nordeste, $27 \%$ ao Sudeste, $11 \%$ ao Sul e $4 \%$ ao Centro-Oeste. 
De acordo com o MDS 5 , o Bolsa Família visa articular as ações sociais e a transferência de renda, com destaque a três pontos: 1) unificação dos programas anteriores e adoção de critérios públicos de elegibilidade do programa. O Bolsa Família unificou quatro programas de transferência de renda que existiam no início de 2002 e que não eram articulados entre si: o Bolsa Escola, o Bolsa Alimentação, o Vale Gás e o Cartão Alimentação. Essa unificação buscou gerar a simplificação de procedimentos e redução dos custos de gestão do programa; 2) acompanhamento do cumprimento das condicionalidades nas áreas de educação e saúde pelos beneficiários, ou seja, da freqüência escolar e dos cuidados básicos com a saúde (calendário de vacinação para crianças entre 0 e 6 anos e a agenda pré e pós-natal para as gestantes e mães em amamentação); 3) o objetivo de formular parcerias com as três esferas do governo, não apenas para implementar o Programa, mas também para priorizar os beneficiários em outros programas. Busca-se, assim, unificar as ações para o alívio imediato da pobreza e proporcionar medidas de médio e longo prazo para uma inclusão social efetiva.

O Programa Bolsa Família, em certas localidades, representa até $43 \%$ da receita disponível no município. Em municípios extremamente pobres, o impacto do Programa é mais forte e provoca dinamização da economia local, como demonstra uma avaliação realizada na região Nordeste ${ }^{6}$. A estratégia de expansão do Programa é de priorizar as regiões e municípios mais pobres (em geral nas zonas rurais) e, em um segundo momento, chegar aos centros metropolitanos e às grandes cidades.

A seleção das famílias beneficiárias é feita a partir do Cadastro Único ${ }^{7}$, observando os critérios de elegibilidade. Podem inscrever-se famílias que têm renda percapita de até $R$ \$120. Aquelas com renda familiar per capita de até $R$ \$ 60 são elegíveis indiferentemente de sua composição. As famílias de renda mensal entre R\$ 60 e R\$ 120 são elegíveis ao Programa apenas se, na composição familiar, existirem crianças e adolescentes de até 15 anos, mulheres grávidas ou mães aleitando. Os benefícios são divididos em básicos e variáveis, de acordo com a composição familiar. Cada família recebe entre $\mathrm{R} \$ 15,00$ e $\mathrm{R} \$ 95,00$ por mês, conforme a sua situação socioeconômica e o número de crianças e adolescentes menores de 15 anos. A tabela a seguir permite visualização das seis situações possíveis no Programa.

Além dos critérios de elegibilidade, existem condicionalidades que devem ser respeitadas. Pelo artigo $6^{\circ}$ da Constituição Brasileira, os direitos sociais devem ser assegurados para o conjunto da população, tendo por objetivo criar as condições fundamentais mínimas para que os sujeitos sociais possam reivindicar acesso às condições necessárias para o desenvolvimento das capacidades essenciais aos indivíduos.

Entre as condicionalidades previstas no PBF, estão a questão da educação e da saúde. Em relação à primeira, existe um controle de matrículas e de freqüência escolar $(85 \%$ de freqüência é o mínimo exigido). De acordo com os Ministérios da Educação e do Ministério do Desenvolvimento Social, após o início do Programa, houve um aumento da freqüência escolar dos beneficiários de todas as idades ${ }^{8}$. É preciso lembrar que antes não havia sempre a informação da freqüência escolar (exceto para os beneficiários do Bolsa Escola) e que, paulatinamente, as escolas começaram a informála com maior regularidade ao MEC. 


\begin{tabular}{|c|c|c|c|c|}
\hline \multicolumn{2}{|c|}{ Critério de elegibilidade } & \multirow{2}{*}{$\begin{array}{l}\text { Ocorrência de } \\
\text { crianças/ adolescentes } \\
0-15 \text { anos, gestantes } \\
\text { e nutrizes }\end{array}$} & \multirow{2}{*}{$\begin{array}{l}\text { Quantidade e } \\
\text { tipo de bebefícios }\end{array}$} & \multirow{2}{*}{$\begin{array}{l}\text { Valores do } \\
\text { benefício } \\
\text { (em reais) }\end{array}$} \\
\hline $\begin{array}{l}\text { Situação } \\
\text { das famílias }\end{array}$ & $\begin{array}{l}\text { Renda } \\
\text { mensal } \\
\text { percapita }\end{array}$ & & & \\
\hline \multirow{3}{*}{$\begin{array}{l}\text { Situação de } \\
\text { pobreza }\end{array}$} & \multirow{3}{*}{$\begin{array}{l}\text { De R\$ } 60 a \\
R \$ 120\end{array}$} & 1 membro & (1) Variável & 15,00 \\
\hline & & 2 membros & (2) Variável & 30,00 \\
\hline & & $3 \mathrm{ou}+$ membros & (3) Variável & 45,00 \\
\hline \multirow{4}{*}{$\begin{array}{l}\text { Situação de } \\
\text { extrema } \\
\text { pobreza }\end{array}$} & \multirow[t]{4}{*}{ Até R\$ 60} & Sem ocorrência & Básico & 50,00 \\
\hline & & 1 membro & Básico + (1) & 65,00 \\
\hline & & 2 membros & Básico + (2) & 80,00 \\
\hline & & 3 ou + membros & Básico + (3) Variável & 95,00 \\
\hline
\end{tabular}

Em relação à saúde, a situação era um pouco mais delicada. No primeiro semestre de 2005, com base em uma amostra de 334 mil famílias - de um universo total de 5,5 milhões de famílias -, apenas 6\% tinham dados registrados pelo Sistema de Vigilância Alimentar e Nutricional (Sisvan) ${ }^{9}$. Essa situação chamou a atenção do governo sobre a necessidade de reforçar o controle da questão alimentar. Diferente de outros programas, o não cumprimento dessa condicionalidade não foi considerado como um fato passível de punição às famílias, mas como um fator de vulnerabilidade dela. Nesse sentido, verifica-se uma mudança de perspectiva no que tange às condicionalidades, traduzida, por exemplo, no discurso de que a escola e a saúde não são apenas um dever dos beneficiários, mas um direito, assim como na relação de responsabilização das falhas do Programa. Diversos programas públicos anteriores atribuíram essa responsabilidade às famílias que não cumpriam as condicionalidades.

Na sua execução, o Programa parte de certas premissas básicas: 1) a necessidade imperativa da associação das políticas de combate à pobreza às políticas de promoção da cidadania; 2) a urgência de estabelecer uma dinâmica de ações que integre o governo federal e os demais membros da federação; 3) a necessidade de focalizar a família como a unidade de ação do Estado; 4) a criação de critérios bastante divulgados para garantir a universalização da cobertura; 5) a importância da participação da sociedade no acompanhamento e controle social do Programa pela criação de instâncias paritárias e intersetoriais; 6) a melhoria dos instrumentos de gestão ${ }^{10}$ e controle dos critérios de elegibilidade.

\section{Definições e mensurações da pobreza: entre a insuficiência de renda e a falta de escolaridade}

A pobreza é reconhecida, de modo simplificado, como uma condição de insuficiência de renda. É definida, ao mesmo tempo, pela renda per capita e pela situação de desigualdade na distribuição de renda. A redução da pobreza é trabalhada como sendo intimamente ligada ao crescimento econômico e à diminuição das desigualdades. No Brasil, as experiências de redução da pobreza são tradicionalmente relacionadas aos períodos de expansão econômica. No entanto, crescimento econômico não implica redistribuição de renda, o que é claramente constatado no País: apesar de ser um dos 
países mais ricos em termos de PIB, é também detentor de uma das mais desiguais distribuições de renda do mundo ${ }^{11}$.

Ademais, existe forte conexão, no Brasil, entre o nível de educação e a pobreza. Os dados da PNAD de 1997 já confirmavam claramente a relação entre o nível de escolaridade do chefe da família e a probabilidade de que a família seja pobre. Segunda essa pesquisa, $42 \%$ das famílias brasileiras eram comandadas por uma pessoa que tinha no máximo três anos de estudos. Entre as famílias cujo chefe nunca havia estudado (23\% das famílias), 58\% estavam abaixo da linha da pobreza. Nas famílias em que o chefe tinha estudado entre 1 e 3 anos (19\% das famílias), 45\% estavam abaixo da linha de pobreza. Por outro lado, as famílias nas quais o chefe tinha 12 anos ou mais de estudos, a pobreza estava presente apenas em 1,9\% das famílias.

Outro dado importante é a incidência da pobreza em diferentes faixas etárias. Havia incidência de maior pobreza entre os jovens: quase $50 \%$ das crianças de 0 a 6 anos e quase $46 \%$ das crianças de 7 a 14 anos estavam abaixo da linha da pobreza. Abaixo da linha de indigência, os índices eram de $5 \%$ e $22 \%$, respectivamente. Isso demonstra que a pobreza atinge, sobretudo, a população infanto-juvenil, um argumento utilizado para justificar a escolha do PBF para as famílias com crianças de até 15 anos. Os dados mais atuais do PNAD, apresentados adiante, mostram um pouco da evolução da situação de pobreza e da precariedade face à educação na última década.

\section{A abordagem da renda: pobreza e extrema pobreza}

Pela medição utilizada internacionalmente, sugerida pela ONU e especificada pelo Banco Mundial, os que vivem com renda de até US $\$ 1$ por dia (aproximadamente $R \$ 2,20 / R \$ 66$ por mês) situam-se sob a linha da extrema pobreza e até US\$ 2 por dia ( $\mathrm{R} \$ 132 /$ mês), sob a linha da pobreza. O Bolsa Família não respeita esse parâmetro, como mostra a tabela. Uma outra medida defendida considera os que se encontram na linha da pobreza aqueles que recebem até $1 / 2$ salário mínimo (R\$175) e, na linha da indigência, aqueles que ganham até $1 / 4$ do salário mínimo ( $\mathrm{R} \$$ 87,50). O Programa Bolsa Família usa também uma medida inferior.

De todo modo, existem elementos que tornam mais complexos os cálculos: 1) a renda não monetária para o cálculo das pessoas e das famílias. É o caso, por exemplo, do cidadão que tem uma pequena horta, cria galinhas, recebe ajuda de um vizinho, vive gratuitamente na casa de outros. A POF (Pesquisa Nacional de Orçamento Familiar), do IBGE, indica a quantidade de gastos e renda não monetários, medida não levada em conta pelo $\mathrm{PBF}^{12}$; 2) diante das discussões intermináveis sobre as linhas de pobrezas e diferentes modos de medição, alguns pesquisadores e políticos acreditam que a melhor forma de mensurar não é pela renda, mas pelo consumo (situação na qual a POF seria imprescindível); 3) a monetarização da economia cria uma pressão imensa sobre as camadas mais pobres (sobretudo nas zonas rurais). Por exemplo, há mais ou menos 20 anos, boa parte da população rural utilizava fogão de lenha e encontrava "combustível" em qualquer lugar. Atualmente, é preciso comprar um botijão de gás que custa, em média, R\$ 30. Para os habitantes das zonas urbanas, isso já faz parte dos cálculos, mas, para os moradores da zona rural, esse preço impacta significativamente seu orçamento. 
O Departamento Intersindical de Estatística e Estudos Sócio Econômicos (Dieese) $^{13}$ apresenta, mensalmente, o chamado "salário mínimo necessário" ${ }^{14}$ (ou seja, aquele de acordo com o preceito constitucional), pelo qual se estima que, para viver com dignidade, um trabalhador deveria receber, no mínimo, em janeiro de 2007, R\$1.565,61. Esse valor, em termos estatísticos, situaria uma família na classe média.

O Estado brasileiro investiu, em 2006, 0,5\% do PIB, ou seja, R \$ 8,5 bilhões no Programa Bolsa Família ${ }^{15}$, uma pequena porcentagem das despesas sociais totais, que representaram 9,8\% do $\mathrm{PIB}^{16}$. A maior parte dessas despesas sociais refere-se ao déficit do sistema de aposentadoria do setor público. A definição do orçamento a ser dedicado ao Programa (e às iniciativas de combate à pobreza) é uma questão-chave, pois demonstra qual a prioridade dada a essas questões. Por outro lado, é o próprio sistema econômico que gera e mantém a situação de pobreza no País. O papel do Programa Bolsa Família, sozinho, é de aliviar, emergencialmente, os quadros de pobreza, combater a pobreza e a fome, garantir a segurança alimentar e contribuir para a promoção do acesso à rede de serviços públicos, estimulando a emancipação sustentada das famílias. Nesse sentido, ele tem provado ser muito eficiente, segundo as diversas avaliações divulgadas ${ }^{17}$. Apesar disso, uma verdadeira priorização econômica e política do combate à pobreza e à precariedade em suas mais diversas formas, por meio de uma reforma estrutural, mostra-se, mais do que necessária, urgente.

\section{Família e educação}

A partir dos anos 1990, os programas de renda mínima elegeram as famílias pobres com crianças e adolescentes como a categoria-alvo do combate à pobreza atual e futura. Tratava-se de um investimento em recursos humanos na tentativa de integrar de forma mais durável a população jovem e pobre nas redes públicas de educação. O complemento de renda ofertado pelos programas visava aliviar os constrangimentos materiais e permitir a essa juventude sair da extrema pobreza pela educação. Os programas tinham como objetivo, assim, a redução

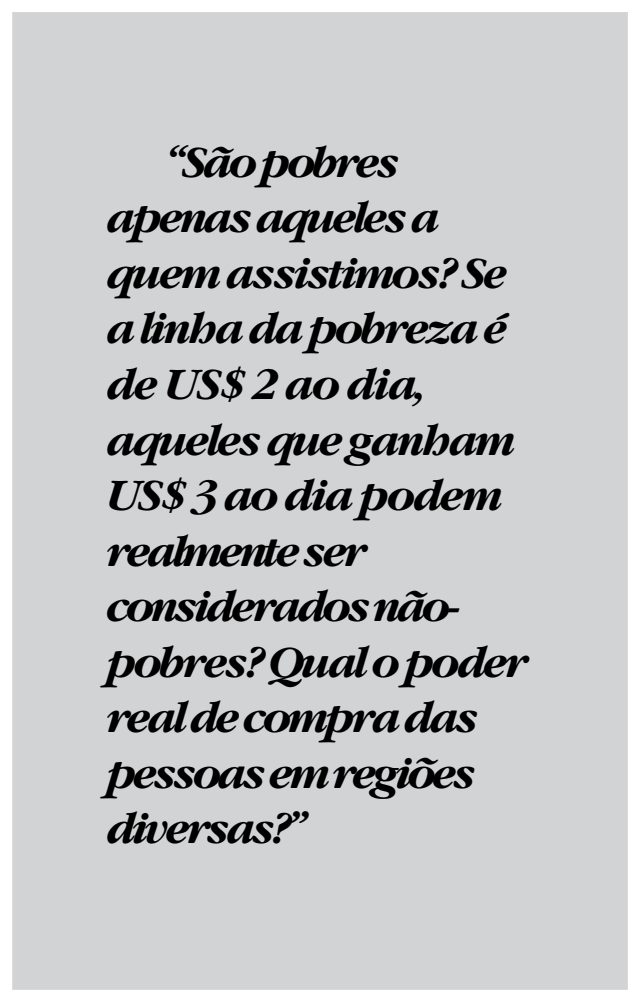

das desigualdades de oportunidades pela ampliação dos anos de escolaridade e, conseqüentemente, o aumento da probabilidade de futuramente gerar sua própria renda.

A pobreza familiar exerce grande influência sobre a inserção precoce no mercado de trabalho, pois o custo de manter uma criança na escola é muito alto para os pobres (seja porque estar na escola 
implica custos materiais, seja porque não há produção de renda no curto prazo). Assim, as crianças entram cedo no mercado do trabalho, abandonam as escolas, tornam-se adultos com baixa escolarização e alguma experiência de trabalho, reforçando os mecanismos de reprodução da pobreza, em um ciclo no qual "a pobreza de hoje cria a pobreza do amanhã" (FonseCA, 2001, p. 219).

Esse argumento é a matriz dos programas de renda mínima familiar no Brasil. O pagamento de uma renda mínima é vinculado ao compromisso das famílias de manter as crianças na escola. Desse modo, as famílias pobres podem dispensar a ajuda econômica das crianças e adolescentes, ao mesmo tempo em que aumentam e fortalecem a escolarização de seus descendentes.

\section{O modelo familiar do Bolsa Família}

Houve grande mudança no conceito de família no Brasil. Os laços familiares ultrapassam hoje os laços de sangue e abarcam também a chamada família ampliada.

Por algum tempo, o Estado trabalhou com um conceito estrito de família, que se traduzia em uma situação em que pais ou responsáveis legais habitavam, sob o mesmo teto, com crianças de até 14 anos, que poderiam ser filhos consangüíneos ou pelas quais os adultos tornaram-se juridicamente responsáveis. Diversos programas demonstraram, porém, que a idéia de família era formada por um leque de relações de sangue e afinidade, assim como de relações familiares não biológicas e não jurídicas.

A família é hoje também reconhecida como uma rede de relações de reciprocidade que opera segundo uma lógica de direitos e obrigações, de solidariedade e lealdade. Não se atribui às relações sangüíneas ou jurídicas mais importância do as relações de afinidade e solidariedade, mesmo não havendo regularização jurídica da situação. Isso significa que é necessário trabalhar com desenhos diferentes de famílias. A Lei no 10.836/2004, que cria o Programa Bolsa Família, tem como conceito de família:

Art. $2^{\circ}$

$\int 1^{\circ}$ Para fins do disposto nesta Lei, considera-se:

I - família, a unidade nuclear, eventualmente ampliada por outros indivíduos que com ela possuam laços de parentesco ou de afinidade, que forme um grupo doméstico, vivendo sob o mesmo teto e que se mantém pela contribuição de seus membros;

As mulheres foram escolhidas para serem as responsáveis legais e "recebedoras" do beneficio. Essa decisão inscrevese numa busca de igualdade entre homens e mulheres, visando reduzir a dependência econômica das mulheres, assim como aumentar a possibilidade de que as crianças recebam o beneficio e tenham uma certa estabilidade.

Existe, porém, uma consideração não menos importante que deve ser feita em relação à atribuição do beneficio às mulheres. Por um lado, essa iniciativa busca assegurar a proteção das crianças e a distribuição diferenciada de poder no lar, o que é muito significativo. Por outro, essas atribuições externas de significação e interpretação da masculinidade e feminilidade reforçam os papéis clássicos de gênero, nos quais o lar e as crianças são de responsabilidade das mães, o que não é uma ação necessariamente sábia do Estado. Ao mesmo tempo, na pesquisa de campo realizada, uma nova tensão (velada, às vezes) entre os casais pode ser 
observada, gerada pelos problemas de autoestima dos homens diante do desemprego e do sentimento de impotência para o sustento econômico de sua família. São questões delicadas porque são decisões que buscam a proteção das crianças, mas geram outras formas de sofrimento em razão da questão simbólica e material dos papéis de seus responsáveis. Para o momento, não há uma solução para o assunto.

\section{$A$ adequação do Programa às populações indígenas e quilombolas}

Os quilombos ou comunidades quilombolas são comunidades tradicionais, com culturas, normas de produção e regras de conduta específicas. Formam territórios independentes onde a propriedade é coletiva e a produção, comunitária. Existem, atualmente, entre 2 mil e 4 mil comunidades, somando 2 milhões de pessoas. Apesar de terem direito às terras, muitas comunidades sofrem com os inúmeros conflitos agrários e a inacessibilidade à água potável.

A população indígena é constituída de 125 etnias distribuídas em 580 terras indígenas. Ela representa 734.127 índios, dos quais $38 \%$ estão abaixo da linha da pobreza. Cerca de 32\% são indivíduos entre 0 a 14 anos. Assim como os quilombos, os grupos indígenas têm uma organização social, familiar e produtiva distinta e regras de conduta próprias. Para ambos os grupos, mostrou-se necessário adaptar as diretrizes gerais do Programa a essas especificidades, seja pela adoção de uma definição diferente de linha da pobreza, formulada por meio de outros indicadores (e não somente a renda), seja por um entendimento diferenciado do conceito de família. Entre os quilombolas e os indígenas, diferentes unidades familiares vivem sob o mesmo teto, e a compreensão de família é variável. É necessário, assim, que cada unidade familiar autodeterminada inscreva-se em cadastros diferentes, mesmo compartilhando o mesmo domicílio.

Em princípio, o titular do cartão continua sendo a mulher, mas o responsável legal pode ser determinado de acordo com a lógica da organização familiar de cada comunidade. Os benefícios podem ser retirados a cada dois meses para racionalizar a locomoção até os bancos. É preciso, ainda, que seja disponibilizado transporte público pelas prefeituras e instituições que trabalham com as comunidades.

Nas terras indígenas, existem 150.285 estudantes matriculados em 2.232 escolas indígenas e 7.500 professores, dos quais $88 \%$ são indígenas, caso em que as condicionalidades de educação podem ser respeitadas. Entre os quilombolas e indígenas que não têm escolas ou unidades de saúde, porém, a falta dessas estruturas e o conseqüente não cumprimento das condicionalidades não implica a privação dos benefícios.

\section{O desafio educacional}

A associação entre a distribuição de uma renda mínima e a educação das crianças e adolescentes visa romper com a lógica da assistência paternalista. As crianças que não vão às escolas pela necessidade de ajudar suas familias trabalhando tornamse adultos não qualificados para o mercado de trabalho e reproduzem o ciclo vicioso da pobreza pela "transmissão hereditária da pobreza". A idéia é de aliviar imediatamente os constrangimentos financeiros e alimentares e, no médio prazo, possibilitar a geração autônoma de renda pela inserção no mercado de trabalho.

Nos últimos 12 anos, houve grande investimento governamental para a 
educação fundamental. Em conseqüência disso, desde 2002, de acordo com a PNAD, foi registrada uma melhoria do nível de escolarização de crianças de 5 a 17 anos. Considerando os grupos de idade correspondentes ao ensino pré-escolar, fundamental e médio, verificou-se, de 1999 a 2004, uma queda no número de crianças e adolescentes que não freqüentavam a escola: de $29 \%$ a $18,2 \%$ no grupo de 5 a 6 anos; de $4,3 \%$ a $2,8 \%$ no grupo de 7 a 14 anos; e de $21,5 \%$ a $17,8 \%$ no grupo de 15 a 17 anos. Nesse período, a inserção de crianças e adolescentes na população estudantil aumentou em todas as regiões. Isso contribuiu para a redução do analfabetismo e para o aumento do nível de instrução da população.

A taxa de analfabetismo de pessoas com 10 anos ou mais caiu de $12,3 \%$, em 1999, a $10,4 \%$, em 2004 e baixou no grupo de 10 a 14 anos de 5,5\% a 3,4\%. No Nordeste, a taxa era de $12,8 \%$ e caiu para $8 \%$, no mesmo período. Ainda assim, essa região continua com os piores índices de educação, coincidindo com os piores índices de pobreza. Na população de 25 anos ou mais, a média de estudo aumentou de 6,4 anos para aqueles que trabalham e de 7,1 anos para aqueles que não trabalham. Para a população de mais de 10 anos, o nível de instrução é maior no grupo de mulheres que no grupo de homens. No entanto, no nível mais elevado de instrução, há mais homens que mulheres. Isso é ainda devido ao efeito da época na qual a educação das mulheres era menos valorizada.

Como dito anteriormente, o Programa Bolsa Família tem como uma de suas condicionalidades a educação de crianças de 6 a 15 anos, com a previsão de controle de matrícula e freqüência escolar. Um aumento na freqüência escolar foi registrado em beneficiários de todos os grupos de idades.
Existem diversas críticas feitas à questão da escolaridade no Programa, sobretudo, em comparação ao Bolsa Escola. Esta polêmica não será tratada aqui, todavia, mais adiante, serão abordados alguns desafios do Programa, entre eles, a educação. Um aspecto essencial diz respeito à qualidade da educação ofertada em todo o território nacional.

Entre a população adulta, encontram$\mathrm{se}^{18}$ casos de pessoas que estudaram de 3 a 4 anos, mas que são, efetivamente, analfabetos funcionais, ou seja, que conseguem ler, mas não compreendem o que lêem e só sabem fazer as operações matemáticas básicas. Existem melhorias visíveis na educação fundamental, mas apenas a presença na escola não significa necessariamente uma educação adequada. O caminho do combate e emancipação da pobreza que passa pela educação exige uma ótima qualidade de ensino para que, no longo prazo, tenha o efeito esperado.

\section{Desafio do gerenciamento administrativo do Programa Bolsa Família}

Uma das críticas ao Programa Bolsa Família, nem sempre abordadas, refere-se ao seu gerenciamento, sobretudo em nível estadual e municipal. O sistema de gestão de um programa normalmente passa pelo planejamento, cadastramento (e seleção, pois nunca há recursos suficientes à demanda), distribuição de bens ou serviços, controle (acompanhamento, monitoramento e avaliação) e toda a estrutura logística e profissional que o programa requer. Para uma iniciativa dessa envergadura, assim como para um país da dimensão do Brasil, com as diferenças regionais que existem, a gestão é um desafio imenso. 
No planejamento de programas públicos anteriores, em geral, os próprios estados arcavam com a capacitação para o gerenciamento do programa, e o custo de financiamento ficava entre $10 \%$ a $25 \%$ do orçamento total do programa ${ }^{19}$.

O custo de gerenciamento não é publicamente discutido no Programa Bolsa Família, apesar de ser um custo embutido significativo. Nem sempre leva-se em consideração que, em certas prefeituras nas quais funciona o Programa Bolsa Família, há apenas uma dezena de servidores que acumulam diversas funções. Em alguns municípios, poucas pessoas são responsáveis por milhares de cadastros ${ }^{20}$; em outros, as organizações são mal equipadas. O Programa Bolsa Família ainda não conseguiu oferecer toda a ajuda técnica necessária a essas demandas, o que não é um desafio trivial.

Em termos práticos e logísticos, é mais fácil gerir programas com 25 mil famílias em prefeituras bem equipadas e com um pessoal bem qualificado, do que gerir um programa com 44 milhões de pessoas em áreas distintas, com realidades diferentes e com possibilidades logísticas distintas. Nas críticas públicas e comparações com outros programas de menor escala já implementados, essa constatação não é necessariamente considerada, o que acaba enviesando, mesmo não intencionalmente, essas análises ${ }^{21}$.

Nos últimos quatro anos, 44 milhões de pessoas passaram a receber o benefício e integrar efetivamente o sistema público de saúde e de educação (com a exceção dos quilombolas). Passaram, também, a transitar mais pelas prefeituras e secretarias que gerem o Programa Bolsa Família, bem como bancos ou lotéricas, o que impõe imensa pressão sobre estruturas e serviços. Trata-se de uma demanda sem precedentes para diversos organismos estaduais e municipais, o que exige uma resposta de qualidade que esses organismos nem sempre estão equipados a fornecer. É um desafio considerável para o Programa Bolsa Família, mas que continua sendo subavaliado.

Entre os meses de julho e agosto de 2006, foi realizada uma pequena pesquisa de campo em quatro estados: Goiás, Bahia, Alagoas e Pernambuco. A amostra pode não ser considerada representativa em quantidade. No entanto, as 50 entrevistas realizadas com beneficiários, assim como as conversas informais com não beneficiários, membros dos governos (federal, estadual, municipal), comerciantes, proprietários de terras, minorias étnicas, comunidades de pescadores, entre outros, resultaram em algumas impressões e pistas que indicam qualitativamente algumas abordagens que poderiam ser adotadas, bem como questionamentos que podem e devem ser feitos. A seguir, serão discutidas brevemente algumas dimensões levantadas nessa pesquisa: a questão do registro civil, a da educação, o Programa de Erradicação do Trabalho Infantil (PETI), a saúde e o trabalho.

\section{O problema do registro civil}

Um tema que aparecia recorrentemente nas conversas com os beneficiários era a questão das pessoas que precisam do Bolsa Família, mas não têm acesso a ele pela falta dos documentos necessários, basicamente a certidão de nascimento ou a carteira de identidade dos adultos ou das crianças. As justificativas da ausência desses documentos eram as mais diversas: "os pais não registraram porque sempre moraram no interior e não precisavam", "os pais não eram registrados e não registraram os filhos", "perderam os documentos 
(em mudanças de estado, enchentes, roubos, em outras tragédias pessoais)", "não sabem aonde ir para tirar", "não têm dinheiro sobrando para pagar transporte ou os documentos" ou são casos de mulheres que fugiram com os filhos de exmaridos violentos e esqueceram de pegar os documentos, etc. Muitas dessas pessoas já tentaram inscrever-se no Programa Bolsa Família mesmo sem os documentos, mas, obviamente, só participaram de parte do processo de seleção.

Nas falas de beneficiários e beneficiários potenciais, havia sempre um misto de ignorância de como proceder, a quem recorrer para pedir ajuda, como normalizar a situação e, ao mesmo tempo, um sentimento de injustiça que se traduzia em colocações como: "Como um papel pode ser mais importante que a fome da gente?", "O fato de eu não ter um papel dizendo isso, não significa que o que digo não seja verdade", "Fulana é minha vizinha há 25 anos, eu vi todos os seus filhos nascerem, eu poderia testemunhar que os filhos são dela mesmo e que ela é ela mesma" ou "Eu entendo que é para a segurança deles [do governo], mas deve existir algum modo para que eles não sejam 'passados para trás' e, ainda assim, que aqueles que não têm os documentos recebam a ajuda de que tanto precisam".

Esses discursos, assim como o estado de extrema vulnerabilidade social das pessoas que não têm documentos (para receber benefícios e diversos outros direitos e deveres) demanda articulação dos cartórios de registro civil com os programas sociais, sobretudo por ocasião dos grandes cadastramentos ou reavaliações de cadastros.

Para os que estão no limite ou abaixo da linha da pobreza, mesmo um pequeno deslocamento pode representar um custo imenso à família. Muitas delas se sentem, realmente, "esquecidas" e "invisíveis" para o resto da sociedade. Temem que, além do custo financeiro (que muitos testemunharam não estarem seguros se terão retorno), servidores públicos duvidem deles, tratem-nos mal, briguem ou humilhem-nos de um modo ou de outro. Em vários depoimentos, é comum a frase: "há alguns anos tentei resolver isso, mas fui tão mal recebido que prometi nunca mais voltar". Nota-se que não se trata de uma questão de "orgulho ferido" (termo utilizado pelos próprios beneficiários entrevistados), mas de estabelecer um nível mínimo de dignidade no tratamento. As condições de vida material já são bastante precárias e muitos dos constrangimentos materiais e físicos não podem ser evitados. Assim, os constrangimentos simbólicos e morais que podem ser evitados o são, uma escolha racional em termos da proteção da auto-estima, ainda que, em termos práticos, cause outras dificuldades.

\section{Educação}

De modo geral, os beneficiários entrevistados expressaram um grande contentamento com a escola e relataram uma melhoria na relação com diretores, professores e com o ambiente escolar e no aprendizado das crianças. Muitas famílias disseram que pararam de sofrer constrangimentos porque, com o Programa Bolsa Família, podem comprar o material escolar. Em alguns casos, houve questionamentos sobre atitudes de alguns professores e diretores, assim como algumas questões da merenda escolar: "ouvi no rádio que a verba aumentou para a merenda, mas na quinta-feira ela acaba na escola. Temos de reclamar porque tem algo de errado acontecendo então". As 
mães participam das reuniões de pais e mestres e demonstram acompanhar os acontecimentos escolares.

No entanto, uma dificuldade que surgiu com a implementação do PBF é o fato de que, hoje, há, no mínimo, 22 milhões de crianças que antes não estavam necessariamente dentro das salas de aula ${ }^{22}$. Sobretudo antes do Bolsa Escola, as escolas tinham um mecanismo "não oficial" de retirar das escolas os alunos que repetiam de ano e perdiam a motivação de continuar os estudos, alunos "bagunceiros" que de tanto serem expulsos de sala deixavam de freqüentar as aulas e estudantes com dificuldades de aprendizado. Além disso, a partir de certa idade, se a criança não estava aprendendo ou não apresentava bom desempenho, a escolha de abandono escolar passava a ser óbvia para seus pais e, às vezes, para a própria criança.

O aumento do número de crianças inscritas e que efetivamente freqüentam a escola gera novas demandas logísticas (de material escolar, merenda, salas de aula), como também demandas pedagógicas que muitas das escolas não estão preparadas para enfrentar. Por exemplo, a presença de alunos que repetem o ano escolar cria situações em que, em uma mesma sala de aula, haja crianças, por exemplo, de 7 a 12 anos, de 9 a 14 anos. Para os professores, isso constitui um desafio novo: como gerir crianças e adolescentes, na mesma sala, de diferentes idades, vivências e sentimentos? Como fazer com que essa convivência seja construtiva para todos e que nenhuma parte sinta-se mal no processo de aprendizado? Como atender melhor os repetentes? Como não preterir uns em relação a outros? São desafios pedagógicos, logísticos, orçamentários, de convivência entre alunos e mesmo de sensibilidade dos professores, que não encontraram ainda soluções práticas em diversas escolas e que são vividos diariamente por todo o corpo escolar.

Por outro lado, as mães estão mais presentes $^{23}$ e exigentes: querem um tratamento adequado e de respeito aos filhos por parte de professores, merendas corretas para todos, material escolar melhor, entre outros.

\section{Programa de Erradicação do Trabalho Infantil (PETI)}

Em dezembro de 2005, o Programa Bolsa Família foi unificado ao Programa de Erradicação do Trabalho Infantil. O PETI foi criado para eliminar as chamadas piores formas de trabalho infantil no País, aquelas consideradas perigosas, penosas, insalubres ou degradantes, entre as quais podem ser citadas as atividades em carvoarias, olarias, no corte de cana-de-açúcar, nas plantações de fumo e nos lixões.

O PETI concede uma bolsa às famílias desses meninos e meninas em substituição à renda que as crianças traziam para casa. Em contrapartida, as famílias têm que matricular seus filhos na escola e fazê-los freqüentar a jornada ampliada. Incluem-se famílias com crianças e adolescentes na faixa etária dos 7 aos 15 anos. Para receber a bolsa do programa, as famílias assumem compromissos com o governo federal, garantindo uma freqüência escolar mínima, o afastamento definitivo das crianças e adolescentes menores de 16 anos do trabalho, a participação das famílias nas atividades sócio-educativas e de ampliação e geração de renda, assim como a participação nas ações de controle exercidas pelos municípios. Com a unificação com o Bolsa Família, a freqüência escolar exigida passou a ser de $85 \%$ (era $75 \%$ antes da unificação). A bolsa mantém o valor mais elevado - seja o do Bolsa Família, seja o do PETI, que oferecia uma 
bolsa mais elevada para a zona rural do que para a zona urbana.

Existe um desafio de ordem logística e orçamentária, como relata a coordenadora do PETI de Formosa, no Estado de Goiás. Nesse município, a jornada ampliada é constituída de uma série de atividades como o acompanhamento escolar para realização dos deveres de casa, aulas de capoeira, vôlei, futebol, artes, artesanato, computação e música, entre outras possibilidades. Durante a jornada ampliada, é oferecido um lanche e, nas férias escolares, atendimento odontológico, disponibilizado por uma unidade móvel ${ }^{24}$.

Quando da visita em Formosa de Goiás, o PETI atendia 831 crianças, das quais a metade estava integrada ao Programa Bolsa Família. Nesse município, existiam, em julho de 2006, 5,5 mil famílias beneficiárias do Bolsa Família e mais 12 mil cadastros em análise. Se todas as famílias beneficiárias do Bolsa Família participassem da jornada ampliada, isso representaria entre 5 mil e 15 mil (supondo que as famílias têm em média de um a três filhos) crianças e adolescentes a mais a serem atendidos.

Se nesse cálculo fossem incorporadas mais 4 mil familias entre os 12 mil cadastros em análise (pela renda das famílias desprovidas da região, esse número provavelmente seria maior), serão de 4 mil a 12 mil jovens a mais a serem atendidos na jornada ampliada. O PETI em Formosa apresenta, porém, uma estrutura e orçamento para atender menos de mil crianças, quando precisaria organizar-se para receber entre 9 mil e 27 mil crianças e adolescentes. Isso significa necessidade de ampliação da infra-estrutura, de contratação de monitores e profissionais para o acompanhamento dos jovens na jornada ampliada, de mais material e, obviamente, mais orçamento.

\section{Saúde}

Com o acompanhamento da saúde das crianças beneficiárias do Bolsa Família, mais de 11 milhões de famílias passaram a recorrer efetivamente aos postos e unidades de saúde. A regularidade na prestação de atenção à saúde no âmbito do PBF representa, por outro lado, aumento considerável da carga de trabalho de postos de saúde, implicando, em certos casos, contratação de de pessoal e melhor organização das dinâmicas de atendimento e triagem. As famílias que passam a ter mais acesso ao serviço, por sua vez, são informadas de seus direitos e passam a exigi-los. Um caso evidente é o da farmácia popular, que tem sido cada vez mais requisitada pelos usuários das unidades de saúde. Na região em que a pesquisa ocorreu, os beneficiários mostraram-se, de modo geral, satisfeitos com a ação dos agentes de saúde, que os visitam em casa e agendam-lhes consultas. Afirmaram, porém, que, no posto de saúde, muitas vezes, o atendimento ainda era complicado.

As mães tornaram-se mais presentes na escola de seus filhos e o mesmo foi relatado por servidores do sistema público de saúde. Elas são mais exigentes com relação à qualidade do tratamento e ao fornecimento de medicamentos, assim como do atendimento nas unidades de saúde.

\section{Trabalho}

A dimensão trabalho continua sendo uma das questões-chave do combate à pobreza e da integração social, como Castel explica, e um dos desafios-chave para o Programa Fome Zero. A maior parte dos beneficiários entrevistados sabia que nesse Programa havia a possibilidade de capacitar os adultos para a inserção no mercado de trabalho, mas nenhum dos 50 entrevistados tinha sido convidado para 
algum tipo de capacitação ou inserção no mercado de trabalho como iniciativa do governo até então. $\mathrm{O}$ interesse de reintegrar-se de modo mais estável ao mercado de trabalho foi repetidamente mencionado, pois os entrevistados compreendem que é um caminho para a emancipação da pobreza e da dependência do governo, muito mal vistas por outros cidadãos $^{25}$. As famílias preocupam-se igualmente com a inserção de seus filhos no mercado. A forma como essa inserção será realizada não estava clara para os beneficiários e provavelmente deve ser mais difundido. Nesse meio tempo, a maioria faz "bicos" e muitos pensam em outras formas de investimentos e trabalhos que possam gerar-lhes renda: comprar um tanque para lavar roupa para fora, vender chicletes e bombons em shows, fazer doces para vender na rua, trabalhar em olarias no verão, vender picolé na praia no verão, etc.

$\mathrm{Na}$ zona rural, os programas ligados à agricultura pouco a pouco criam mudanças. O Programa Nacional de Fortalecimento da Agricultura Familiar (Pronaf), em sua versão Pronaf B, muito difundido no Nordeste e que tem como objetivo combater a pobreza rural, é alvo de diversas críticas ${ }^{26}$, mas tem efetivamente gerado algumas mudanças. A soma de programas como o Bolsa Família e o Pronaf permite que algumas famílias deixem de trabalhar para proprietários e trabalhem em suas próprias terras. Se menos pessoas estão disponíveis para trabalhar para grandes e médios proprietários, a oferta diminui. Se a oferta diminui, o preço da diária do trabalhador rural pode ser aumentado, uma forma indireta de geração e redistribuição de renda.

$\mathrm{Na}$ região ribeirinha do rio São Francisco, no Estado da Bahia, por exemplo, foi observado, nos últimos anos, um aumento do trabalho de agricultura familiar e da diária de vários cultivos. A diária no corte de cana-de-açúcar continua sendo a mais baixa - $\mathrm{R} \$ 7,00-$, mas em outras plantações há variação de $\mathrm{R} \$ 9$ a $\mathrm{R} \$ 15$. Isso ainda não chega ao valor de um salário mínimo para um trabalhador rural que trabalha cinco dias por semana, mas significa um aumento considerável da diária. Em conversa com proprietários, revelou-se que o sindicato dos trabalhadores rurais sugerira

"Como Simmel demonstra, a forma de calcular'quem assistimos', a escolha dopuiblico-alvo, os critérios deabordagem (àpobreza), ascondicionalidades e eventuais penalidades deum programarefletemuma concepçãode sociedade, de investimento sociale, em uiltima instância, umafilosofiade Estado.”

que os trabalhadores exigissem no mínimo $\mathrm{R} \$ 13$ como diária. Os proprietários afirmavam, por sua vez, que a associação de proprietários tinha estipulado um teto máximo de $\mathrm{R} \$ 12$. A luta salarial continua forte na região, mas, nos últimos anos, os trabalhadores rurais têm conseguido acumular algumas conquistas.

Durante o verão (férias escolares), as famílias, incluindo as crianças a partir de 
7 anos, vão em conjunto trabalhar nas plantações, sobretudo no corte de cana. Como nesse período não há aulas e, assim, não há controle de freqüência, as crianças não deixam de ir à escola para trabalhar e fazem-no para aumentar a renda familiar e mesmo gerar uma pequena poupança. Trata-se de uma brecha no controle da erradicação do trabalho infantil, que talvez venha a ser corrigido com a unificação do PBF com o PETI e por outras formas de controle. Na lógica da sobrevivência familiar, no entanto, trata-se de uma decisão racional.

\section{Preconceitos sociais e morais}

Existe, no discurso moral, o "bom pobre" e o "mau pobre"27, assim como uma herança moralizadora das ajudas - se a pessoa vai aceitá-la, deve sujeitar-se a uma espécie de "catequese de comportamentos", o controle social e os julgamentos morais que a acompanham. Nenhuma transferência de dinheiro é gratuita no sentido moral e social.

Vários discursos ressaltam o efeito indesejável da concessão de benefícios. Um deles é que os benefícios seriam tantos que os beneficiários passam a não querer trabalhar mais. Essa visão reflete, mais do que um preconceito, falta de informação sobre a situação na qual boa parte da população brasileira vive. De fato, o PBF gera um alívio imediato na vida familiar, mas não é suficiente para que as famílias vivam unicamente dele. Ademais, o trabalho não é compreendido apenas como um modo de ganhar renda, mas também como meio de inserção social que lhes permite serem reconhecidas e respeitadas como cidadãs úteis ao conjunto da sociedade. A maioria das pessoas desempregadas oficialmente ou que não têm empregos estáveis fazem trabalhos informais e temporários para aumentar a renda familiar, bem como trabalhos não remunerados que fortalecem os laços de solidariedade.

Outro preconceito moral parece estar presente nas críticas relacionadas ao destino dos benefícios. Existe uma "economia das relações sociais", conceito estudado pela antropologia e sociologia sob títulos diferentes, podendo-se citar Marcel Mauss e Pierre Bourdieu entre os clássicos e Laé e Murard, que tratam disso em L'argent des paurres $^{28}$, mostrando que a economia não é compreendida somente pela renda, mas também pela ação (e sentido) social que a renda e os próprios laços sociais criam.

No trabalho de campo, foi observado que a maioria das famílias entrevistadas gasta os recursos recebidos na sobrevivência direta e urgente, mas outras fazem investimentos. É o caso de duas beneficiárias: uma comprou um tanque para lavar roupa para fora, que o aluga para vizinhas e o empresta para amigas. Outra parcelou a compra de um DVD com parte do Bolsa Família para criar um cinema comunitário em sua casa, cobrando $\mathrm{R} \$ 0,50$. Nas festas de crianças, os filmes são oferecidos gratuitamente. O que elas estão fazendo é capitalizar a renda, investir para que possam gerar mais renda, bem como fortalecer seus laços sociais e solidários.

Nesse sentido, gastar parte do dinheiro do Bolsa Família para fazer um penteado no cabeleireiro para participar de um casamento pode ser considerado um investimento de trocas simbólicas: o gasto para se arrumar em um quadro de precariedade é uma deferência a essa festa, aos noivos e aos convidados e, em um momento de maior precariedade ou necessidade, as pessoas assim "honradas" poderão retribuir de modo solidário. As mulheres que cuidam das crianças dos outros gratuitamente asseguram que, 
quando precisarem, seus filhos também serão cuidados.

Jean-François Laé e Numa Murard, em L'argent des pauvres, de 1985, já explicitavam que a riqueza é indissociavelmente econômica e social. "A economia em si mesma é material e política. Sobreviver é assegurar as necessidades biológicas e encontrar um lugar (social) na cite $e^{29}(. .$.$) . A$ escala da renda não é o suficiente: pode-se ser rico (financeiramente) ${ }^{30}$ e fraco (socialmente), pobre (financeiramente) e forte (socialmente); a renda subentende e esconde valores contraditórios, de acordo com a origem do dinheiro e sua utilização: valor do trabalho, da ajuda social, do trabalho informal; moral do bom pobre ou do bandido; vida social aberta à cité ou limitada a sua família. Sobreviver é ser capaz de manter-se socialmente. Nesse sentido, as trocas são indispensáveis: mais que a movimentação de dinheiro e de bens, a convivência é obrigatória. É preciso relacionar-se, criar aliados, ou seja, abrir-se, deixar-se ser visto para que os objetos necessários (móveis, tanques, bicicletas) circulem, assim como os objetos dos quais deseja-se se desfazer. Os orçamentos permanecem como um dos elementos (de análise da renda). Mas as trocas demonstram que a cité, longe de ser um espaço amorfo, anárquico, é organizada material e socialmente"(1985, p. 87-88).

Essa experiência diária de economias financeiras e simbólicas é muitas vezes banalizada por assistentes sociais, pela mídia (que tende a denunciar essas trocas como mau uso dos benefícios) e por parte da população, mas é vital para a sobrevivência em quadros de precariedade. Para a maioria da população assistida, a ajuda é inconstante em um vai-e-vem ${ }^{31}$ de governos, ONGs e Igrejas. A experiência de trabalhos precários é também parte desse vai-e-vem. Por outro lado, o que pode ser mais ou menos assegurada é essa solidariedade informal, mantida pela retroalimentação dos laços de solidariedade por intermédio de "investimentos", que nem sempre parecem racionais, mas que se justificam naquela realidade, conforme se depreende de diversos estudos feitos a respeito da importância das trocas simbólicas e solidárias.

Outro preconceito muito explorado pela mídia e outros críticos do Programa no momento em que era realizada a pesquisa de campo referia-se à idéia de que o PBF seria um instrumento político de manipulação eleitoral, uma forma de clientelismo clássica. No entanto, é importante explicitar duas considerações básicas para uma avaliação objetiva da ação do governo: 1) na esfera pública estatal de direitos, inscreve-se a obrigação de preservar o direito à subsistência dos habitantes de uma nação. Em setembro de 2006, foi aprovada no Congresso a Lei Orgânica da Segurança Alimentar (Losan) que consolida a concepção de uma renda mínima como direito do cidadão. Essa lei rompe com a associação desse direito às iniciativas de um partido ou de um governo e insere-o na agenda social brasileira como obrigação legal do Estado. A não garantia desse direito representa uma séria violação aos direitos fundamentais das pessoas e lesão do direito à vida ${ }^{32}$; 2) a meta criada inicialmente pelo MDS para a aplicação do PBF foi respeitada em todos os anos do governo, não sofrendo alterações e mantendo-se indiferente às mudanças de conjeturas políticas.

$\mathrm{Na}$ amostra aqui apresentada, que não é quantitativamente, mas é qualitativamente representativa dos discursos dos beneficiários do Programa Bolsa Família, a grande maioria das pessoas demonstrou satisfação não diretamente com o 
Programa, mas com outras iniciativas como o Pronaf, o acesso à eletricidade, o aumento de remédios nas farmácias populares, o acesso à saúde e melhorias na escola. A relação com a vizinhança, de acordo com os entrevistados, também melhorou com o fortalecimento de laços de solidariedade e de novas amizades.

A transferência de renda desempenha visivelmente um papel importante na garantia de uma autonomia mínima, na capacidade de planejar o futuro (diminuindo o fator de imprevisibilidade total de renda), na dinamização da economia local, no consumo e na qualidade alimentar, entre outros. No entanto, na fala dos beneficiários, a transferência de renda não é espontaneamente citada quando questionados sobre as mudanças de qualidade de vida e sobre o governo. Esse resultado merece ser explorado em uma amostra efetivamente representativa, mas parece sinalizar um comportamento político bem diferente do que aquele tradicionalmente imaginado.

Outro preconceito moral que faz parte dos discursos sociais e privados e que pode ser abordado aqui é a questão da "responsabilização dos pobres". A tendência de responsabilizar os pobres pela situação precária em que vivem geram a culpa que eles sentem de não conseguirem emancipar-se (individualismo negativo e não positivo). Esse preconceito suscita ainda uma discussão sobre o papel do Estado no exercício de compensações efetivas por resultados perversos impostos a pessoas que não são necessariamente responsáveis, mas que pagam o custo do sistema e de mudanças nocivas (Murard, 2003). Ou seja, questiona o modo como o Estado cria políticas compensatórias para um sistema econômico que gera ou mantém, para parte da população, uma situação de precariedade e como ela é responsabilizada pela dependência dessas mesmas políticas.

\section{Conclusão}

Existem diferentes abordagens da pobreza, diversas formas de medi-la e distintos modos de combatê-la. A maneira de definir e lidar com a pobreza revela conflitos de várias ordens: estatísticos, de classe, de partidos políticos, entre agências de pesquisa, para citar alguns, e impõe escolhas políticas e econômicas desafiadoras. Levanta, também, questões controversas: são pobres apenas aqueles a quem assistimos? Se a linha da pobreza é de US\$ 2 ao dia, aqueles que ganham US\$ 3 ao dia podem realmente ser considerados não-pobres? Qual o poder real de compra das pessoas em regiões diversas?

Por trás de uma abordagem limitada de pobreza (à renda, por exemplo) existe a dimensão desigualdade, que passa pelas questões da educação, do trabalho, das estruturas políticas e sociais e sua reprodução, étnicas, de gênero e de reconhecimento social, gerada, entre outros, por uma economia que privilegia elites minoritárias e uma situação agrícola com injustiças atrozes. Não se pode esquecer que o Brasil é considerado um dos países mais ricos do mundo $^{33}$, de modo que não existem motivos materiais para tamanha desigualdade social. Diante de uma situação econômica e política tão excludente, a pergunta de Castel pode ser reapresentada: "Qual a tolerância de uma sociedade democrática que invalida uma grande parte de sua população?".

Como visto, o Bolsa Família é apenas um dos programas dentro da iniciativa do Fome Zero e une outros programas complementares aos de transferência de 
renda, como o de alfabetização e educação de jovens, a cargo do Ministério da Educação; o Pronaf, do Ministério do Desenvolvimento Agrário, o Luz para Todos, do Ministério das Minas e Energia e o PETI, do Ministério de Desenvolvimento Social e Combate à Fome (MDS).

O MDS trabalha atualmente com 22 programas espalhados em 13 ministérios, o que demanda um enorme esforço de articulação política e logística. Frente aos desafios da emancipação da pobreza, abordar prioritariamente a renda e a educação parece ainda bastante limitado (e o é, em diversos sentidos). Um programa dessa envergadura precisaria efetivamente consolidar uma articulação política e social mais profunda em vista das múltiplas face da precariedade, da insegurança e da desafiliação social. Esse é o caminho iniciado, mas ainda não plenamente realizado pelo MDS.

Educação e trabalho apresentam-se hoje como fortes prioridades da inserção social dos cidadãos e combate à pobreza no Brasil. Outros desafios não trabalhados neste texto, mas que são importantes e que devem ser pensados e discutidos foram colocados por André Gorz, em 1998: o sistema capitalista traz em si um problema estrutural de desemprego. Não é uma falha do sistema capitalista, mas parte constituinte dele, e países desenvolvidos e com menos desigualdades sociais que o Brasil já precisam fazer frente a esses problemas ${ }^{34}$.
No Brasil, face à precariedade da inserção na educação e no trabalho, essas questões ainda não se apresentam, mas não deixarão de aparecer no futuro. Ainda assim, diante da situação de extrema pobreza, mesmo não sendo a solução única, perfeita e finalizada, é notável o que o Programa Bolsa Família tem sido capaz de atingir no alívio imediato da precariedade de renda e mesmo na dinamização de economias.

Diversas críticas podem e devem ser feitas a inúmeros aspectos do Programa Bolsa Familia. Participação e controle social são, também, mais do que necessários na gestão do Programa, embora, de certo modo, já façam parte dele por intermédio da criação de conselhos. O PBF tem se mostrado eficaz naquilo que se propõe, o que não exclui, porém, a necessidade de reformas estruturais para garantir a integração e coesão social mais igualitária e digna no longo prazo. Além da crítica, entretanto, parece igualmente pertinente rever a abordagem à pobreza e a gestão do programa ou mesmo criar outros programas e levar adiante a reforma estrutural almejada por tantos. Isso faz parte não só do exercício democrático de participação cidadã, mas também de um pacto social pelo combate à pobreza e às desigualdades sociais em uma sociedade que visa à democracia efetiva.

(Artigo recebido em novembro de 2006. Versão final em março de 2007) 


\section{Notas}

1 Simmel não explicita quem criou essa definição.

2 Uma bela exceção é o programa chileno "Chile Solidario", que funciona mais como um sistema em que diversos aspectos relativos à precariedade e pobreza são tratados simultaneamente. O programa mostra-se ainda limitado em diversos sentidos, mas traz essa inovação.

3 Para conhecer mais sobre o sistema de proteção francês, indica-se o livro de Castel, assim como La protection sociale, de Numa Murard. Sobre o sistema de proteção social brasileiro, na bibliografia deste artigo encontram-se algumas referências importantes do IPEA.

4 Segundo o relatório interno de avaliação "Programa Bolsa Família: dois anos", do MDS.

5 Relatório interno de avaliação "Programa Bolsa Família: dois anos".

6 Um estudo importante foi o de Rosa Maria Marques: "A importância do Bolsa Família nos municípios brasileiros", no Cadernos de Estudos Desenvolvimento Social em Debate, publicado pelo MDS.

7 Cadastro que unificou os quatro programas anteriores e que registra aqueles que não estavam inscritos.

8 Idem nota 6.

9 A Política Nacional de Alimentação e Nutrição propõe para o Sisvan o monitoramento da situação alimentar e nutricional, de modo a agilizar os seus procedimentos e a estender sua cobertura em todo o País. A consolidação do sistema é feita, especialmente, com o apoio de Centros Colaboradores em Alimentação e Nutrição e as Áreas Técnicas Estaduais em Alimentação e Nutrição existentes na quase totalidade dos estados e em centenas de municípios brasileiros <http:// sisvan.datasus.gov.br/apresentacao.asp $>$.

10 O Programa conta hoje com um Conselho de Gestão do Programa Bolsa Família, constituído por um grupo de deliberação composto de titulares do Ministério do Desenvolvimento Social, do Ministério da Educação, do Ministério da Saúde, do Ministério do Planejamento, Orçamento e Gestão, do Ministério da Fazenda, da Casa Civil da Presidência da República, da Caixa Econômica Federal e representantes de outros organismos públicos, da sociedade civil e de instituições privadas.

11 Em 2005, o Brasil estava em $4{ }^{\circ}$ lugar no ranking dos países de pior distribuição de renda do mundo. Os outros países eram: Serra Leoa, República Centro Africana e Suazilândia. No Relatório do Desenvolvimento Humano 2006, publicado pelo PNUD, o Brasil ocupa o $10^{\circ}$ lugar no ranking de pior distribuição de renda do mundo, de uma lista com 126 países, à frente de Colômbia, Bolívia, Haiti e cinco países da África Subsaariana.

12 Existe um debate muito interessante e ainda não solucionado de cálculo de renda e despesas, que talvez poderá indicar um caminho mais eficiente para futuras análises da pobreza. Parte desse debate é tratado justamente pelos pesquisadores da POF.

13 Vide site, atualizado frequentemente: <http://www.dieese.org.br/>.

14 O salário mínimo necessário é produto de uma ponderação de despesas familiares em uma família de dois adultos e duas crianças. A Constituição Brasileira determina, em seu art. $7^{\circ}, \mathrm{IV}$, que o salário mínimo é "fixado por lei, nacionalmente unificado, capaz de atender a suas necessidades vitais básicas e às de sua família, com moradia, alimentação, educação, saúde, lazer, vestuário, higiene, transporte e previdência social, com reajustes periódicos que lhe preservem o poder aquisitivo, sendo vedada sua vinculação para qualquer fim". 
15 Ver artigos de Lautier, B. sobre o assunto (citado também nesta bibliografia).

16 A título de comparação, na Argentina (que viveu uma grave crise econômica em 2002), o programa social "Plan Familias" representa $0,12 \%$ do PIB nacional.

17 Por diversos institutos e pesquisadores autônomos: IPEA, organismos da ONU e pesquisadores acadêmicos (vide bibliografia).

18 Ver os relatórios sobre a educação no Brasil fornecida pela Unesco nos últimos dez anos.

19 Trata-se de uma média genérica dos orçamentos de diversos programas de políticas públicas que se pode observar em seus relatórios de gestão.

${ }^{20}$ Isso foi notado em Formosa de Goiás, onde no máximo, uma quinzena de atendentes era responsável pelo cadastramento digital de mais de 12 mil famílias, sem contar as 5 mil famílias já beneficiárias do Programa Bolsa Família.

21 Tal fato foi apontado por especialistas e antigos gestores do Programa Bolsa Escola em algumas regiões ou de programas de renda em estados que já tinham desenvolvido algumas iniciativas (como Brasília e Campinas, por exemplo).

${ }^{22}$ Esse dado já foi constatado em avaliações do Bolsa Escola, mas aqui também refere-se a relatos dos próprios servidores das escolas.

${ }^{23}$ Idem nota 19.

${ }^{24}$ Todas essas atividades foram relatadas pela coordenadora do PETI de Formosa, no Estado de Goiás. É provável que em outros estados algumas dessas atividades variem.

${ }^{25}$ É um visão colocada pelos beneficiários em diversas entrevistas. É também uma idéia muito apresentada na mídia.

${ }^{26}$ Uma das críticas é que há famílias que terminam se endividando porque não há um programa de gerenciamento da renda difundido com a concessão do empréstimo. Tais críticas vêm de ONGs locais (no Nordeste) e mesmo de pessoas vinculadas à Comissão Pastoral da Terra, entre outros.

27 São termos muito utilizados por teóricos franceses a respeito da pobreza, cujas fontes são diversas. Neste artigo, apresenta-se a terminologia utilizada por Numa Murard.

${ }^{28}$ O título completo é L'argent des pauvres - La vie quotidienne em cité de transit. (O dinheiro dos pobres - a vida cotidiana nas cités de trânsito).

29 Refere-se a uma zona urbana onde vivem as camadas mais populares na França. Guardam semelhança, no Brasil, aos municípios e comunidades pobres e bairros populares. Em certos casos, as cités podem equivaler às favelas brasileiras mais antigas, que têm casas de alvenaria e um pouco mais de infra-estrutura.

30 Todos os parênteses nesta citação e seus conteúdos foram criados pela tradutora para facilitar a compreensão do texto.

31 O vai-e-vem consiste na inconstância de ajudas e iniciativas na luta contra a pobreza. As instituições atuam por um tempo e depois desaparecem da mesma forma "mágica" - termo utilizado por um beneficiário do PBF - como apareceram.

32 As cortes internacionais de direitos humanos já agem contra violações de direitos civis e políticos, mas podem agir igualmente em processos jurídicos contra Estados que não asseguram os direitos sociais e econômicos mínimos de suas populações.

33 O Brasil foi considerado a $14^{\circ}$ maior economia do mundo, segundo lista divulgada pelo Banco Mundial em 2004 e $10^{\circ}$ lugar na lista do FMI de 2006, ambos de acordo com o PIB nacional.

${ }^{34}$ Como a França, Bélgica e Alemanha, entre outros. 


\section{Referências bibliográficas}

Barros, Ricardo P.; Carvalho, Mirela de; Franco, Samuel. O indice de desenvolvimento da familia (IDF). Texto para discussão no 983 IPEA: Rio de Janeiro, 2003.

Barros, Ricardo P.; Poverty, inequality and macroeconomic instability. Texto para discussão no 750 IPEA: Rio de Janeiro, ago. 2000.

Bourdieu, Pierre La misére du monde. Paris: Seuil, 1993. .Questions de sociologie. Paris: Minuit, 1984/2002. . Le sens pratique. Paris: Minuit, 1980.

Castel, Robert. Les métamorphoses de la question sociale. Paris. Gallimard, 1995.

CunHa, Rosani. Relatório do Conselho Nacional de Segurança Alimentar e Nutricional. 25 de junho de 2005.

Drummond, Clarisse; Rodrigues, Mônica. Acesso das comunidades remanescentes de quilombos ao cadastro único e ao programa bolsa família. Relatório versão preliminar: 01 fev. 2005.

FonseCA, Ana Maria de Medeiros da. Familia e política de renda minima. São Paulo : Cortez, 2001.

Gorz, André. Métamorphoses du travail quête du sens critique de la raison économique. Paris: Galilée, 1988.

IBGE. Oficina de elaboração de documentos metodológicos de referência para o Programa Bolsa família. Comentários sobre o formulário do cadastramento único para programas sociais do governo federal. Brasília: set. 2005.

JR. Carlos A. Os contrastes segundo Vinod. Correio Braziliense. Brasília: 30 jan. 2006.

LAE, Jean François ; MURARD, Numa L'argent des pauvres - La vie quotidienne en cité de transit. Paris : Seuil, 1985.

Licio, Elaine Cristina. A trajetória dos programas de renda minima e bolsa escola no Brasil: o impacto da variável federativa. Dissertação: Universidade de São Paulo, 2002.

Marques, Rosa Maria. A importância do bolsa família nos municípios brasileiros. Cadernos de Estudos Desenvolvimento Social em debate, $\mathrm{n}^{\circ}$ 1, Ministério do Desenvolvimento Social e Combate à Fome: Secretaria Nacional de Renda de Cidadania, Brasília, 2005.

Mauss, Marcel Sociologie et anthropologie. Paris: Puf, 1950/2004.

Medeiros, Marcelo. Os ricos e a formulação de políticas de combate à desigualdade e à pobreza no Brasil. Texto para discussão no 984. IPEA. Brasília: out. 2003, Brasília.

Mesa-Lago C.. Les réformes de la sécurité sociale en Amérique Latine: observations sur le rapport de 2005 de la Banque mondiale. Revue internationale de sécurité sociale vol.58, 2-3, p.115-140, 2005

Ministério do Desenvolvimento Social e Combate à Fome: Secretaria Nacional de Renda de Cidadania, Programa Bolsa Família: gestão e responsabilidades compartilhadas", Brasília, 2004.

Relatório da oficina para elaboração de documentos metodológicos de referência para definição de indicadores de elegibilidade do programa bolsa família e para a revisão do formulário do cadastro único. Brasília, 2005. 
Programa Bolsa Família: dois anos. Brasília, 2004.

Murard, Numa. . La protection sociale. Paris. La Découverte,1988; 2004.

. La morale de la question social. Paris. La dispute, 2003.

Nepr. Acompanhamento e avaliação da implementação do programa de garantia de renda familiar minima da prefeitura municipal de Campinas. fev./dez. 1995. Universidade de Campinas, 1996.

Querino, Ana Carolina; SCHWARZER, Helmut. , Benefícios sociais e pobreza: programas não contributivos da seguridade social brasileira. Texto para discussão n 929. IPEA, Brasília: dez. 2002.

Sadeck, Francisco; Castro, Jorge A; Neto, Manoel; B.M, Duarte, Bruno; Simões, Hellenne. Analise da evolução e dinâmica do gasto social federal:1995-2001. Texto para discussão $\mathrm{n}^{\circ}$ 988. IPEA, ,Brasília, outubro de 2003.

Senarc/MDS. Adequação do Programa Bolsa Família para o atendimento da população indígena. (Nota Técnica). Brasília, 14 de julho de 2005.

- Adequação de Diretrizes do PBF para inclusão das Comunidades Remanescentes de

Quilombos. Nota Técnica. Brasília, 14 de julho de 2005.

Simmel, Georg . Les pauvres. Paris : PUF, 1998 ;2005.

SOARES, Sergei; SOARES, Fabio V. Bolsa família não é incentivo à preguiça. Valor Econômico. Brasília: 2006.

VALENTE, Flavio Luiz Schieck. Fome Zero, política nacional de segurança alimentar e nutricional e a promoção da realização do direito bumano à alimentação adequada. Brasília: 2003.

\section{$\mathrm{Na}$ internet:}

DePARTAMENTO INTERSINDICAL DE ESTATÍSTICAS E ESTUdOS SOCIOECONÔMICOS:

$<$ www.dieese.org.br/>.

Instituto Nacional de Estudos e Pesquisas Educacionais Anísio Teixeira:

$<$ www.inep.gov.br/>.

International Poverty Centre - UNDP: <www.undp-povertycentre.org/>.

Programa das Nações Unidas para o Desenvolvimento - Brasil:

$<$ www.pnud.org.br>

Pesquisa Nacional de Amostras por Domicílios - PNAD - de 1997 e de 2004:

$<$ www.ibge.gov.br/home/estatistica/populacao/trabalhoerendimento/>.

Pesquisa de Orçamento Familiar - POF- de 2002: <www.ibge.gov.br/home/

estatistica/populacao/condicaodevida/pof/analise/ $>$.

Ministério do DESENVOLVIMENTO SOCIAL E COMBATE À FOME : <www.mds.gov.br/>.

Ministério do Desenvolvimento Agrário: <www.mda.gov.br>.

Núcleo de Estudos Agrários e Desenvolvimento Rural: <www.nead.org.br/>.

SISvAN: < http://sisvan.datasus.gov.br/apresentacao.asp $>$. 
Resumo-Resumen-Abstract

A perspectiva brasileira sobre a pobreza: um estudo de caso do Programa Bolsa Família

Sarah Mailleux Sant'Ana

Tendo como pano de fundo a dificuldade de definir a pobreza, este artigo visa retomar parte da discussão sobre o tema, utilizando como estudo de caso o Programa Bolsa Família. Inicia-se com a definição institucional de pobreza dada pelo sociólogo alemão Georg Simmel passando-se, na seqüência, a uma abordagem mais substancial da pobreza e da relação entre trabalho e precariedade, desenvolvida por Robert Castel. Apresenta uma breve descrição do funcionamento do Programa Bolsa Família e alguns aspectos relacionados aos conceitos e modos de tratamento da questão da renda e da educação, bem como da família e dos modelos familiares, baseando-se também nos resultados parciais de uma pesquisa de campo realizada nos estados da Bahia, Pernambuco, Alagoas e Goiás. O texto trata ainda de alguns desafios administrativos na gestão do Programa e os preconceitos morais e sociais recorrentemente veiculados em relação a ele. Por fim, na conclusão, busca retomar a análise do Programa Bolsa Família, seus limites e desafios, defendendo a necessidade de participação de todos em um pacto social contra a pobreza e a desigualdade no Brasil.

Palavra-chave: pobreza; desigualdade; trabalho; Programa Bolsa Família

\section{La perspectiva brasileña de la pobreza: un estudio de caso del Programa Bolsa Familia} Sarah Mailleux Sant'Ana

Poniendo en contexto la dificultad en definir la pobreza, este artículo busca retomar parte de la discusión acerca de ese tema, teniendo como estudio de caso el Programa Bolsa Familia. Se comienza con la definición institucional de pobreza del sociólogo alemán Georg Simmel, pasándonse, a continuación, a un abordaje más substancial de la pobreza y de su relación entre trabajo y precariedad desarrollado por Robert Castel. Presenta una breve descripción del funcionamiento del Programa Bolsa Familia y algunos aspectos asociados a los conceptos y modos de tratamiento de la cuestión de la renta y de la educación, así como de la familia y de los modelos familiares, basandose también en los resultados parciales de una investigación realizada en los estados de Bahia, Pernambuco, Alagoas y Goiás. Este texto destaca posteriormente algunos de los retos administrativos en la gestión del Programa y los prejuicios morales y sociales recurrentemente vehiculados con respecto a ello. Por último, se concluye retomando el análisis del Programa Bolsa Familia, sus límites y desafíos, defendiendo la necessitad de participación de todos en un pacto social contra la pobreza y la desigualdad en Brasil.

Palabra clave: pobreza; desigualdad; trabajo; Programa Bolsa Familia

\section{The Brazilian perspective on poverty: a case study of the Bolsa Familia Program Sarah Mailleux Sant'Ana}

By putting the difficulty in defining poverty into context, this article aims to recount the debate over this issue, presenting the Bolsa Familia Program (the conditional cash transfer program currently being implemented in Brazil) as case study. It begins by exploring the institutional definition of poverty given by the German sociologist Georg Simmel, as well the substantial approach to poverty and its intertwined relation between employment and precarity, developed by Robert Castel. The article then presents a brief overview of the Bolsa Familia Program functioning and some of the aspects related to concepts and modes of treatment of the issues related to income, education, family and family models. This part is based on the partial results of the field research conducted in 
the states of Bahia, Pernambuco, Alagoas and Goias. The paper also highlights some of the administrative challenges of the program management, as well as the moral and social prejudices repeatedly linked to the program. It concludes by reexamining the analysis of Bolsa Familia Program, its limits and challenges and stressing the need of a social pact against poverty and inequality in Brazil.

Key words: poverty; inequality; employment; Bolsa Familia Program

\section{Sarah Mailleux Sant'Ana}

Bacharel em ciência política pela Universidade de Brasília, bacharel em sociologia e antropologia e mestranda em sociologia e filosofia política da Universidade Paris-Diderot (Paris 7). Contato: sarah_ms2@yahoo.com. 